https://doi.org/10.48009/2_iis_2008_494-499

\title{
A CROSS-NATIONAL ANALYSIS OF E-GOVERNMENT IMPLEMENTATION: A RESEARCH NOTE
}

\author{
Saviour L. S. Nwachukwu, saviour_nwachukwu@subr.edu \\ Syed Musab Khalil, syed_khalil_00@subr.edu \\ Ashagre Yigletu, ashagre_yigletu@subr.edu \\ Donald R. Andrews, donald_andrews@subr.edu \\ Southern University and A\&M College
}

\begin{abstract}
This paper examines the implementation of $e$ government in selected countries. Using a sample of 41 countries at various stages of economic development, the study finds that the largest stage (43.9\%) of e-government implementation is publishing - i.e., governmental web sites are used to provide basic information only. The next most common level (36.58\%) of implementation is interactive phase - i.e., citizens are given the information with which to correspond with government via e-mail and chat rooms; forms are also available online. Only a small percentage $(9.76 \%)$ of countries are currently providing egovernment access and interaction at a high level i.e., citizens participate in transactions via digital government; end-to-end online transaction. However, some countries are still at the very beginning stages of e-government $(9.76 \%)-$ i.e., web sites are under construction; thus, no government information or services are provided online. The findings support the general tenet that e-government implementation is affected by a host of factors, including administrative traditions, political culture, institutional maturity, regulatory/policy frameworks, and the availability of technology.
\end{abstract}

Keywords: E-Government, Information \& Communication Technologies, ICTs

\section{INTRODUCTION}

Countries across the globe are making significant investments in e-government capabilities, as a means of enhancing their efficiency and effectiveness. Modern information and communication technologies (ICTs) are seen not only as key enablers of globalization - by facilitating world wide flows of information, capital, ideas, people and products (UNDP, 2001, p. 5; UNDP et. al., 2001), but, also as tools for enhancing transparency and democracy - by creating space and a public sphere for civil society (Lor \& Britz, 2007). E-government applications stand ready to transform communication and interaction between governments and citizens (Lau et. al., 2008; Becker \& Slaton, 2000; Berhel, 2000; Bouras et al., 1998). However, the anticipated milestones would not be possible without significant technological advancements in ICTs.

The potential of ICTs to improve practices and services in variety of fields have been well documented. It has be argued that ICTs would improve service delivery (Bekkers \& Zouridis, 1999), efficiency and effectiveness (Heeks, 2001b), interactivity (DiCaterino and Pardo, 1996), decentralization and transparency (La Porte, De Tong, \& Demchak, 1999), and accountability (Ghere \& Young, 1998; Heeks, 1998, 1999; McGregor, 2001). ICTs have been credited to have altered the services and practices in business, education, research, medicine, and government (Kolko, Wei \& Spyridakis, 2003).

By definition, ICTs are essentially information handling tools - a varied and complex set of hardware and software, and services, that are used to produce, store, process, distribute, and exchange information (UNDP, 2001; Duncombe \& Heeks, 1999). A working definition of the various development programs of the United Nations suggests that:

ICTs cover Internet service provision, telecommunications equipment and services, information technology equipment and services, media and broadcasting, libraries and documentation centers, commercial information providers, network-based information services, and other related information and communication activities. (Adeya, 2001, p.1)

ICTs has been categorized as "old" ICTs (e.g., radio, television, and fixed-line telephone), and "new" ICTs (e.g., computers, satellite, and wireless technology and the Internet) - (UNDP, 2001). The new tools work together better, and blend to form a 
networked infrastructure (e.g., world wide web). However, the truly astounding potential of the "new" ICTs rests in their capacities to connect vast networks across great geographic distances (UNDP, 2001; Dutton, Elberse, \& Hale, 1999; Lau et. al., 2008). The purpose of this paper is to examine the extent of the implementation of information and technology technologies in the provision of governmental services, particularly how the Internet is been utilized by governments to communicate with their citizens.

\section{CONCEPTUAL FRAMEWORK: e-Government}

There are numerous definitions of e-government in the literature (see Yildiz, 2007; Lau et. Al., 2008; Halchin, 2004). However, most of them reflect the theoretical and/or empirical focus of the research work. For example, Budge (2002, p. 331) defines eGovernment as "the systemic use of information communication technologies (ICTs) to support the functions that a government performs for its constituents, typically the provision of information and services."

For the purposes of this study, e-Government is defined as: "the delivery of government information and services through the Internet". This definition is adapted from Reddick \& Frank (2007); and in addition, it fits rather perfectly with the limited scope of this study. However, it is important to clarify that this narrow definition of e-Government focuses on the use of Internet technologies and does not consider other non-Internet ICTs (Reddick \& Frank, 2007; Gronlund, 2005; Grant \& Chau 2005).

There are studies that identified four relationships in the e-government processes: government-togovernment ( $\mathrm{G} 2 \mathrm{G})$, government-to-business $(\mathrm{G} 2 \mathrm{~B})$, government-to-employees (G2E), and governmentto-citizens (G2C) (e.g., Lau et. al., 2008; Balutis, 2001a, 2001b; "eGovernment indicators"). Brown and Brudney (2001) categorize only three relationships - they do not include the G2E relationship. And Yildiz (2003) suggests two additional relationships - Government-to-Civil Societal Organizations (G2SC) and Citizen-toCitizen (C2C). For the purposes of this study, only G2C (government-to-citizens) relationships are examined, and specifically, the degree to which the Internet is used by the government to interact with the citizenry.

In examining G2C relationships, there are models that attempt to describe the e-government processes. For example, Balutis (2001a) identifies four stages of the $\mathrm{G} 2 \mathrm{C}$ process: Information Dissemination,
Forms-Only, End-to-End Electronic Transactions, and Transforming Government. Budge (2002) proposes five stages: Emerging Presence, Enhanced Presence, Interactive, Transactional, and Seamless. And Howard (2001) divides the process into three phases: Publish, Interact, and Transact. Numerous other models that have been proposed to described the e-government processes (see Lau et. al., 2008; Yildiz, 2007). Table 1 is a presentation of the guiding model of this paper. The model is based almost entirely on Howard's (2001) representation of the e-government process, however, with two minor modifications: While Howard's model represents the e-government process as starting with the development of a Web site and publishing (providing) information only, we believe that two earlier stages should be included: (a) Phase 0: No government Web site, but, government information and services exist offline, and (b) Phase 1: Development (construction) of the government Web site - no information is provided online, but, the Web is up and under construction. However, government information and services exist offline. We present these two stages as preceding the phases in the Howard's model:

Publish - e-government has only a basic electronic presence with limited published information.

Interact - citizens can correspond with government via e-mail and chat rooms.

Transact - citizens participates in transactions via digital government; maximized service potential.

\section{METHODOLOGY}

Forty-one countries at various stages of economic development were selected as sample frame for this study. The countries were selected primarily because the English language is either their national language or it is one of their national languages. Specifically, it is expected that since English is a national language, the official government Web site will be in English, and this, in turn, will allow for a more thorough analysis, given the linguistic limitations of the researchers.

To gather the data, the Web sites of the central (national) government were selected as test units. And for each Web site, the home page is analyzed. Specifically, the analysis determines the present stage of the e-government process of each country. Identified links on the home page were followed to determine the resultant information and access level. A score is applied depending on: 
(a) whether (or not) the national government has an established presence on the Internet; and

if a Web site exist, the nature of the information as well as the level of interactivity that the Web site provides ( see Table 1.)

Data was collected over a two-month period. The data was continuously updated in order to record the latest development. The last update was made on Sunday, March 30, 2008.

Table 1

Internet Development Rating Scale

\begin{tabular}{|c|c|c|}
\hline Score & Category & Description \\
\hline 0 & $\begin{array}{l}\text { Non- } \\
\text { Existent }\end{array}$ & $\begin{array}{l}\text { No Governmental website } \\
\text { exists. The Internet is not } \\
\text { currently used as a means to } \\
\text { communicate with the } \\
\text { citizens. }\end{array}$ \\
\hline 1 & $\begin{array}{l}\text { Under } \\
\text { Construction }\end{array}$ & $\begin{array}{l}\text { Website(s) can be found, } \\
\text { however, no information can } \\
\text { be obtained - i.e., an empty } \\
\text { shell. }\end{array}$ \\
\hline 2 & Publish & $\begin{array}{l}\text { Governmental website(s) are } \\
\text { used to provide basic } \\
\text { information only }- \text { e.g., } \\
\text { Addresses and Phone } \\
\text { numbers of offices. }\end{array}$ \\
\hline 3 & Interact & $\begin{array}{l}\text { Citizens are given the } \\
\text { information with which to } \\
\text { correspond with government } \\
\text { via e-mail and chat rooms. } \\
\text { Forms are also available } \\
\text { online. }\end{array}$ \\
\hline 4 & Transact & $\begin{array}{l}\text { Citizens participate in } \\
\text { transactions via digital } \\
\text { government }- \text { End-to-End } \\
\text { digital transactions are } \\
\text { available. }\end{array}$ \\
\hline
\end{tabular}

\section{RESULTS}

The results of the study are presented in Table 2 . The results indicate that, of the 41 countries examined, four $(9.76 \%)$ of them have government Web sites with a score of 4 (End-to-End digital transactions are available), 15 (36.58\%) have government Web sites with a score of 3 (Forms are available online; government email addresses are also available), and $18(43.9 \%)$ have government Web sites with a score of 2 (Information Only). However, there are four countries $(9.76 \%)$ with government Web sites that were not functional, and therefore, were presumed to be under construction. The results indicate that most of the countries are still in the early stages of utilizing the Internet for communicating with their citizens.

TABLE 2

Stage of e-Government Implementation

\begin{tabular}{|l|l|l|l|}
\hline Country & $\begin{array}{l}\text { Size } \\
(\text { Pop. })\end{array}$ & $\begin{array}{l}\text { GDP } \\
(\$ \\
\text { billion})\end{array}$ & $-\begin{array}{l}\text { e-Gov } \\
\text { Score }\end{array}$ \\
\hline $\begin{array}{l}\text { Antigua } \\
\text { Barbuda }\end{array}$ & 81 & 1.079 & 3 \\
\hline Bahamas & 323 & 6.586 & 3 \\
\hline Bangladesh & 148,384 & 70.6 & 3 \\
\hline Barbados & 279 & 3.739 & 3 \\
\hline Belize & 287.73 & 1.304 & 3 \\
\hline Botswana & 1,765 & 11.35 & 2 \\
\hline Brunei & 374 & 12.52 & 2 \\
\hline Dominica & 79 & 0.268 & 3 \\
\hline Gambia & 1,517 & 0.379 & 2 \\
\hline Ghana & 22,113 & 14.89 & 2 \\
\hline Grenada & 103 & 0.553 & 2 \\
\hline Guyana & 751,000 & 0.978 & 3 \\
\hline India & $1,100,000$ & 1090 & 4 \\
\hline Jamaica & 2,651 & 8.905 & 3 \\
\hline Kenya & 34,256 & 29.5 & 4 \\
\hline Lesotho & 1,795 & 1.588 & 3 \\
\hline Malawi & 12,884 & 3.441 & 2 \\
\hline Malaysia & 27,356 & 165 & 4 \\
\hline Maldives & 329 & 1.024 & 2 \\
\hline Mauritius & 1,245 & 7.03 & 2 \\
\hline Namibia & 2,031 & 6.707 & 2 \\
\hline Nigeria & 132,796 & 126.7 & 3 \\
\hline Pakistan & 158,352 & 106.3 & 4 \\
\hline $\begin{array}{l}\text { Papua } \\
\text { Guinea }\end{array}$ & 5,887 & 5.914 & 1 \\
\hline $\begin{array}{l}\text { Saint Kitts \& } \\
\text { Nevis }\end{array}$ & 43 & 0.52 & 2 \\
\hline Saint Lucia & 161 & 0.958 & 2 \\
\hline Samoa & 185 & 0.387 & 2 \\
\hline Seychelles & 81 & 0.733 & 3 \\
\hline Singapore & 4,326 & 153.5 & 3 \\
\hline $\begin{array}{l}\text { Solomon } \\
\text { Islands }\end{array}$ & 478 & 0.358 & 1 \\
\hline South Africa & 47,423 & 274.5 & 3 \\
\hline Sri Lanka & 20,743 & 25.78 & 3 \\
\hline $\begin{array}{l}\text { St. } \\
\text { /Grenadines }\end{array}$ & 119 & 0.528 & 2 \\
\hline Swaziland & 1,032 & 2.674 & 2 \\
\hline Tanzania & 38,329 & 14.11 & 2 \\
\hline
\end{tabular}




\begin{tabular}{|l|l|l|l|}
\hline Tonga & 102 & 0.219 & 1 \\
\hline $\begin{array}{l}\text { Trinidad } \\
\text { Tobago }\end{array}$ & 1,305 & 14.15 & 3 \\
\hline Uganda & 28,816 & 11.14 & 2 \\
\hline Vanuatu & 211 & 0.421 & 1 \\
\hline Zambia & 11,668 & 10.89 & 2 \\
\hline Zimbabwe & 11,376 & 16.17 & 2 \\
\hline
\end{tabular}

Using the scoring framework, the largest category of use is publishing (providing information only 43.9\%), followed by interactive access (e.g., general access with downloadable forms $-36.58 \%$ ). Only a small percent of the countries presently provide high level Internet access to government services (End-toEnd digital transaction $-9.76 \%$ ). However, it is not encouraging to find that at this later stage of the developmental phase of the Internet (and the world wide web), about 10 percent of the countries do not have a functional government Web site with which to communicate with their citizens.

Table 3

Rating Scores - Summary

\begin{tabular}{|l|l|l|l|}
\hline \multirow{2}{*}{ Score } & Category & \multicolumn{2}{|l|}{ Frequency } \\
\cline { 3 - 4 } & Description & Count & \% \\
\hline 0 & No Web Site Found & 0 & 0 \\
\hline 1 & $\begin{array}{l}\text { Web Site Under } \\
\text { Construction }\end{array}$ & 4 & 9.76 \\
\hline 2 & Publishing & 18 & 43.90 \\
\hline 3 & Interactive & 15 & 36.58 \\
\hline 4 & Transactional & 4 & 9.76 \\
\hline & TOTAL & 41 & 100 \\
\hline
\end{tabular}

\section{DISCUSSION}

The findings of this study support the general results that have been reported in other studies. Generally, studies on e-government agree that the vast majority of e-government access provided through the Internet is still in the publishing phase of the process. Only a small percentage of countries are offering egovernment access and services at a high level of interactivity. In addition, when the group of countries that have established high level of access and transactional capabilities are examined, they tend to be advanced countries with significant technological and economic success, as well as populations with high literacy rate. For example, in a cross-national analysis of global e-government, Kim (2007) reported that the performance of egovernment is influenced by economic wealth, education, urbanization, civil liberties, government effectiveness, and the interaction between Internet usage and economic wealth. However, Kim (2007) emphasized that government effectiveness is the most important factor in determining e-government performance. This support the findings of this study, in that some countries with moderate levels of economic development (e.g., Kenya, Malaysia, and Pakistan) are still able to provide high levels of egovernment access and interactivity.

More distinctly, Singh, Das \& Djoseph (2007) reported that the influence of GDP on e-government is achieved through its influence on the development of ICT infrastructure within a country. In order words, GDP is more likely to influence the development of ICT infrastructure, and the level of the ICT development will, in turn, influence the level of e-government. However, higher level of egovernment does not necessarily reflect better governance (Singh, Das \& Djoseph, 2007). The current socio-political situations in both Pakistan and Kenya provide evidence to support this argument.

The findings also reveal that there are countries that are still in the beginning phases of the e-government process. And for the most part, these countries tend to be economically less developed with low literacy rates. The results of this study support the general belief that the implementation of e-government still eludes many developing nations. It is argued that the lack of success may be due to the complexity of the e-government process itself. As a socio-technical system, e-government is highly dependent on a number of factors, including overall institutional maturity, regulatory/policy frameworks, administrative traditions, political culture, sociocultural considerations, and civil liberties (Lau et. al., 2008; Gauld, Goldfinch, \& Dale, 2006; Heeks,2001c; United Nations, 2002; West, 2005; Bolgherini, 2007; Lor \& Britz 2007).

\section{CONCLUSION}

Experts in Information and Communication Technologies have considered the Internet a powerful tool in the war against poverty, illiteracy, and eradication of many of the social ills that plague many nations - especially the less developed countries. This study provides an insight into the process of the implementation of e-government across a diverse sample of developing countries. And though most of the countries in the sample are already implementing some level of e-government, the largest category of access being provided is publishing - i.e., most government Web sites provide 
information only. However, it is important to note that, given the dynamic nature of the Internet environment, it is expected that many of the countries with low level of e-government performance, would take appropriate actions and employ the capabilities of the Internet in interacting with their citizens.

\section{REFERENCES}

1. Adeya, Catherine Nyaki, (2001). Information and Communication Technologies in Africa: A Review and Selected Annotated Bibliography 1990-2000, Oxford, UK: International Network for the Availability of Scientific Publications (INASP). Available at: http://www.inasp.info/file/343/information-andcommunication-technologies-in-africa-a-reviewand-selective-annotated-bibliography-19902000.html. Accessed February 1, 2008.

2. Balutis, A. (2001a). E-government 2001a, Part I: Understanding the challenge and evolving strategies. The public manager, Spring (p. 33).

3. Balutis, A. (2001b). E-government 2001b, Part II: Evolving strategies for action. The public manager, Spring (p. 41).

4. Brown, M. M., \& Brudney, J. L. (2001, October). Achieving advanced electronic government services: An examination of obstacles and implications from an international perspective. Paper presented at the National Public Management Research Conference, Bloomington, IN.

5. Becker, T., \& Slaton, C. (2000). The future of teledemocracy. Westport, CT: Prager.

6. Bekkers, V. J. J. M., \& Zouridis, S. (1999). Electronic service delivery in public administration: Some trends and issues. International Review of Administrative Sciences, 65(2), 183-196.

7. Berhel, H. (2000). Digital Politics 2000. The vote's. In The Web's potential in the political process is still lacking. Communications of the ACM, 43(11), 17-22.

8. Bolgherini, Silvia (2007), "The Technology Trap and the Role of Political and Cultural Variables: A Critical Analysis of the E-Government Policies", Review of Policy Research, vol. 24 (3), pp. 259-275.

9. Bouras, C., Destounis, P., Garofalakis, J., Tzimas, J., Triantafillou, V., \& Zarafidis, P. (1998). A cooperative environment for local government: An Internet-Intranet approach. Journal of Telematics, 16(1-2), 75-84.

10. Budge, Eduardo Contreras (2002), "Foundations of E-Government", in Digital Opportunities for Development. Available at:
learnlink.aed.org/Publications/Sourcebook/chapt er6/Foundations_egov_modelofuse.pdf. Accessed February 1, 2008.

11. DiCaterino, A., \& Pardo, T. A. (1996). The World Wide Web as a universal interface to government services. Available at: http://www.ctg.albany.edu/publications/reports/ world wide web/world wide web overview.pd f. Accessed March 1, 2008.

12. Duncombe R., and R. Heeks 'Information, ICTs and Small Enterprise: Findings from Botswana.' Manchester: University of Manchester, Institute for Development Policy and Management, Working Paper 7, 1999. Available at: http://unpan1.un.org/intradoc/groups/public/docu ments/NISPAcee/UNPAN015541.pdf Accessed March 1, 2008

13. Dutton, W. H., Elberse, A., \& Hale, M. (1999). A case study of a Citizen's guide to elections. Communications of the ACM, 42(12), 49-54.

14. eGovernment indicators for benchmarking eEurope. (2001). Available at: http://www.epractice.eu/index.php?page=docum ent\&doc $\mathrm{id}=3271 \&$ doclng $=6$. Accessed March 30, 2008.

15. Gauld, R., \& Goldfinch, S. Dale,T. (2006).

Dangerous enthusiasms: E-government, computer failure, and information system development. Dunedin, NA: Otago University Press.

16. Ghere, R. K., \& Young, B. A. (1998). The cybermanagement environment: Where technology and ingenuity meet public purpose and accountability. Public Administration and Management: An Interactive Journal, 3(1). Available at: http://www.pamij.com/gypaper.html. Accessed March 1, 2008.

17. Grant, G., \& Chau, D. (2005). Developing a generic framework for e-government. Journal of Global Information Management, 13(1), 1-30.

18. Gronlund, A. (2005). State of the art in e-gov research: Surveying conference publications. International Journal of Electronic Government Research, 1(4), 1-25.

19. Halchin, L. E. (2004). Electronic government: Government capability and terrorist resource. Government Information Quarterly, 21, 406-419.

20. Heeks, R. (1998). Information systems and public sector accountability. The University of Manchester, Institute for Development, Policy and Management Information, Systems, Technology and Government: Working Papers Series, Number 1/1998. Available at: 
http://unpan1.un.org/intradoc/groups/public/documen ts/NISPAcee/UNPAN015474.pdf

Accessed March 1, 2008

21. Heeks, R. (1999b). Public sector accountability: Can IT deliver? Available at: http://www.sed.manchester.ac.uk/idpm/research/ publications/wp/igovernment/short/igov_sp01.pd f. Accessed March 1, 2008.

22. Heeks, R. (2001a). Building e-governance for development: A framework for national and donor action. The University of Manchester, Institute for Development, Policy and Management Information, Systems, Technology and Government: Working Papers Series, Number 12/2001. Available at: http://www.sed.manchester.ac.uk/idpm/research/ publications/wp/igovernment/igov_wp12.htm. Accessed March 1, 2008.

23. Heeks, R. (2001b). Understanding e-governance for development. The University of Manchester, Institute for Development, Policy and Management Information, Systems, Technology and Government: Working Papers Series, Number 11/2001. Available at: http://unpan1.un.org/intradoc/groups/public/docu ments/NISPAcee/UNPAN015484.pdf. Accessed March 1, 2008.

24. Heeks, R. (2001c). Building e-governance for development: A framework for national and donor action. I-government working paper series No. 12. Institute for Development Policy and Management, Manchester, U.K. Available at:

http://www.sed.manchester.ac.uk/idpm/research/publ ications/wp/igovernment/documents/igov_wp12. pdf Accessed March 1, 2008

25. Howard, M. (2001). E-government across the globe: How will "e" change government? Government finance review (p. 1).

26. Kim, Cho-Kyun (2007), "A Cross-national Analysis of Global E-government", Public Organization Review, vol. 7 (4), pp. 317-329.

27. Kolko, Beth E., Carolyn Y. Wei and Jan H. Spyridakis (2003), "Internet Use in Uzbekistan: Developing a Methodology for Tracking Information Technology Implementation Success", Information Technologies and International Development, vol. 1 (no. 2), Winter, pp. 1-19.

28. La Porte, T. M., De Jong, M., \& Demchak, C. C. (1999). Public organizations on the World Wide Web: Empirical correlates of administrative openness. Available at: http://www.cyprg.arizona.edu/publications/correl at.rtf. Accessed March 1, 2008.
29. Lau, T. Y., Mira Aboulhoson, Carolyn Lin, and David J. Atkin (2008), "Adoption of egovernment in three Latin American countries: Argentina, Brazil and Mexico", Telecommunications Policy, 32, pp. 88-100.

30. Lor, Peter Johan, and Johannes Jacobus Britz (2007), "Is a knowledge society possible without freedom of access to information?", Jouranl of Information Science, vol. 33 (4), pp. 387-397.

31. McGregor, E. B., Jr. (2001). Web page accountability: The case of public schools. Paper presented at the National Public Management Research Conference, Bloomington, IN.

32. Reddick, Christopher G. and Howard A. Frank (2007), "The perceived impacts of e-government of Florida and Texas City managers", Government Information Quarterly, 24, pp. 576594.

33. Singh, Harminder, Amit Das, and Damien Djoseph (2007), vol. 2007 (20), pp. 632-648.

34. UNDP Evaluation Office, 2001. Information Communications Technology for Development, Essentials 5, September.

35. UNDP et al. 2001. Creating a digital dynamic:

Final report of the Digital Opportunities Initiative(DOI). New York: UNDP. http://www.opt-init.org/ Available at: http://www.markle.org/downloadable assets/doif inalreport.pdf Accessed March 15, 2008.

36. United Nations online network in public administration and finance. (2002). Benchmarking e-government: A global perspective. Assessing the progress of the UN member states. New York: UNPAN. Available at:http://unpan1.un.org/intradoc/groups/public/do cuments/UN/UNPAN021547.pdf Accessed March 15, 2008

37. West, D.M. (2005). Global e-government, 2005. Center for Public Policy, Brown University. Available at: http://www.insidepolitics.org/egovt05int.pdf Accessed March 15, 2008.

38. Yildiz, Mete (2007), "E-Government research: Reviewing the literature, limitations, and ways forward", Government Information Quarterly, 24, pp. 646-665. 